\title{
Confusio: Reference to Roman Law in the House of Lords and the Development of English Private Law
}

James Lee*

Abstract - This paper examines the use of Roman law by members of the House of Lords in three recent decisions: Fairchild $v$. Glenhaven Funeral Services, 2002 U.K.H.L. 22; Foskett v. McKeown, [2001] 1 A.C. 102; and OBG v. Allan, 2007 U.K.H.L. 21. The contrasting views of Professor Peter Birks and Professor Sir Basil Markesinis are considered, and it is argued that within these decisions can be seen the value of reference to Roman law.

\section{Introduction}

This paper explores the references to Roman law in several recent important decisions of the House of Lords on English private law. In The Goring, ${ }^{1}$ Sir John Donaldson, M.R., described the conflict between the Lord High Admiral and the common law courts in the fourteenth century:

The Lord High Admiral not only spurned juries . . but he administered a law of his own derived in part from such out-

* Lecturer, Birmingham Law School, University of Birmingham. The first version of this paper was presented at the Fourth Biennial Conference on the Law of Obligations at the National University of Singapore in July 2008, and I am grateful to those who attended the session for helpful insights, particularly Professor Graham Virgo and Dr. David Fox, and the organizers, Professor Andrew Robertson and Associate Professor Tang Hang Wu. I acknowledge the support of the Society of Legal Scholars Academic Purposes Fund in contributing to the cost of my attendance at that Conference. A later draft was presented at Edinburgh Law School in November 2008, when I appreciated the observations of Dr. Paul du Plessis and Professor John Blackie. I have greatly benefited from discussions with my colleague Sarah Green on the tort of conversion and on the paper generally with Birke Häcker and Professor Paula Giliker. Any errors are my own.

$1 \quad 1987$ Q.B. 687. 
landish sources, as the common law courts saw it, as Roman law, the Rolls of Oleron of general average fame and what seemed appropriate to Mediterranean trading nations. Clearly such pretensions could not be tolerated and in 1389 an Act was passed entitled "An Act concerning what things the admiral and his deputy shall meddle."

Here we shall examine the modern House of Lords' attitude to the "outlandish sources" of Roman law when developing English private law. The consideration of the resort to Roman law is valuable because it draws attention to the background and training of several of the Law Lords who have been most prominent in the shaping of private law during the past decade. Judges educated in mixed jurisdictions will naturally draw on Roman law, as their systems have been influenced by both the common and civil law traditions. Lord Hope of Craighead, a Scot, is the first Deputy President of the Supreme Court. With the retirements of Lord Hoffmann and Lord Scott of Foscote ahead of the transition from the House of Lords to the Supreme Court, our court of final appeal will have no South African judges for the first time since the appointment of Lord Steyn in January 1995. ${ }^{3}$ What is more, the House of Lords can currently boast of having, in Lord Rodger of Earlsferry, one of the world's leading authorities on the subject. ${ }^{4}$

2 Id., 701.

3 P. Carmichael and B. Dickson, eds., The House of Lords: Its Parliamentary and Judicial Roles (Oxford 1999), 131-32. Lord Hope of Craighead, and Lord Rodger of Earlsferry, are Scots lawyers, while Lord Hoffmann (former Second Senior Law Lord), Lord Scott of Foscote and Lord Steyn are all South African. Although there were four years in which these five Lords were serving Lords of Appeal in Ordinary (between Lord Rodger's appointment in 2001 and Lord Steyn's retirement in 2005) it would appear that on no occasion did all five comprise the Appellate Committee. They were, however, members of the enlarged Committee of nine of their Lordships in Attorney General's Reference No. 2 of 2001, 2003 U.K.H.L. 68 (December 11, 2003), and of the Privy Council which heard the conjoined appeals in Boyce \& Anor v. R. (Barbados), 2004 U.K.P.C. 32; Matthew v. The State (Trinidad and Tobago), 2004 U.K.P.C. 33; and Watson v. R. (Jamaica), 2004 U.K.P.C. 34, decided on July 7, 2004. On the appointment of judges, see note 50 below.

4 Lord Rodger was previously Fellow in Law at New College, Oxford, where he completed his D.Phil. under David Daube. Unusually for a serving Law Lord, Lord Rodger has continued to publish independent articles (as opposed to revised texts of extra-judicial speeches). Some recent pieces by Lord Rodger on Roman law are "Objections and Exceptions: the Palingenesia of D.43.24.17," Cambridge L.J., 64 (2005), 79; "What did Damnum Iniuria Actually Mean?," in A. Burrows and A. Rodger, eds., Mapping the Law: Essays in Memory of Peter Birks (Oxford 
The focus here will be on three recent cases in which the House of Lords has referred to Roman law, each in a particularly vibrant and controversial area of private law. The first case, Fairchild v. Glenhaven Funeral Services, ${ }^{5}$ considers causation in the law of torts. It is an instructive starting point because Lord Rodger sets out the Roman position clearly. The second case, Foskett v. McKeown, ${ }^{6}$ also raises a question on causation, and the issue of the relationship between property and the law of unjust of enrichment. The analysis will be developed when considering Foskett because, unusually, the two members of the House who referred to Roman law disagreed over how the Roman jurists would have classified the claim in question. Drawing on the use of Roman law in these cases, the next section of the paper will construct an answer to the question raised by $O B G v$. Allan ${ }^{7}$ over whether the tort of conversion should extend to all forms of intangible property, by investigating how the Romans might have approached the claim. In so doing, it is hoped to demonstrate that there is value in, and hope for, the study of Roman law when seeking to develop English private law.

This project was conceived as a result of noting the interesting references to Roman law in these three leading cases. But it is also worthwhile in the light of the work of leading scholars. Whether in his lectures on the Institutes of Justinian to undergraduates $^{8}$ or his published work, Peter Birks, the late Regius Professor of Civil Law at the University of Oxford, always identified a clear and accurate taxonomy as one of the key goals of private law. ${ }^{9}$ Birks saw the work of Gaius, Tribonian, and the other jurists as essential tools in attaining that goal. But in his later writings, he lamented the decline of regard for Roman law in

2006), 421; and "A Very Good Reason for Buying a Slave Woman?," Law Q. Rev., 123 (2007), 446. See text to note 82 below for mention of the "Rodger effect."

52002 U.K.H.L. 22.

6 [2001] 1 A.C. 102.

2007 U.K.H.L. 21.

8 See A. Pretto-Sakmann, "You Never Can Tell with Bees': Good Advice from Pooh for Students of the Lex Aquilia," in A. Burrows and A. Rodger, eds., Mapping the Law: Essays in Memory of Peter Birks (Oxford 2006), 495.

9 "I suspect that, until fairly recently, most British lawyers would have had to reach for the dictionary in order to discover what taxonomy is, far less why it should matter to them. But the late Peter Birks changed all that by his work in the particular context of unjust enrichment." A. Rodger, "Foreword," in E. Descheemaeker, The Division of Wrongs: A Historical Comparative Study (Oxford 2009), vii. 
legal education. Professor Markesinis has recently launched a savage attack on the use of Roman law, particularly in his "deliberately controversial" 10 book from 2003, Comparative Law in the Courtroom and Classroom: the Story of the Last Thirty Five Years, and his work with Professor Jörg Fedtke, ${ }^{11}$ going so far as to question the utility of Professor Birks's Roman writings.

Building on the work of Birks, and an excellent recent book by James Gordley, ${ }^{12}$ this article endeavors to demonstrate that the use of Roman law in three of the most important private law decisions of the House of Lords since the turn of the century suggests that there is a continued and real value in the subject. In all three of the cases here discussed, the Roman library provides a wealth of wisdom and a conceptual framework in which these universal legal problems can be debated. Indeed, Markesinis and Fedtke invite responses to their work: "Such speculation may provoke counter-arguments and encourage a different interpretation. We should welcome such a development. That is what scholarship is all about: debate and exchange of views."13

I certainly do not intend to suggest that Roman law can or should always be cited in lectures or cases, regardless of the nature of the problem in issue. But modern engagement with the subject shows that it is neither "a subject doomed to spend its life in search of an audience"14 nor guilty of "dragging down comparative law." 15 We may here offer a justification for the continued study and teaching of Roman law, and, where appropriate, for the reference to Roman law at the appellate level, in the face of modern challenges. This paper is therefore an apology, not a eulogy: I come to praise Roman law, not to bury it.

10 B. Markesinis, Comparative Law in the Courtroom and Classroom: the Story of the Last Thirty Five Years (Oxford and Portland 2003), xiv.

11 Most recently, B. Markesinis, Engaging with Foreign Law (Oxford and Portland 2009) (with Jörg Fedtke). For ease of reference, although there is some repetition of points from Courtroom and Classroom and Engaging with Foreign Law, citations in this article will be to Courtroom and Classroom where any overlap occurs.

12 J. Gordley, Foundations of Private Law: Property, Tort, Contract, Unjust Enrichment (Oxford and New York 2006).

13 Markesinis with Fedtke (note 11), 18.

14 Id., 69.

15 Id., 45. 


\section{The "Utility of Roman Law": Markesinis's Crusade and Birks's Lament}

\section{A. Markesinis's Crusade}

In the Foreword to Professor Markesinis's Comparative Law in the Courtroom and Classroom, Lord Phillips of Worth Matravers states that "[f]or more than 30 years Professor Basil Markesinis has been conducting a crusade."16 That crusade is to vitalize comparative law through offering a coherent methodology, encouraging comparatists to package their writings so that practitioners and judges can, and will, make use of it. Markesinis argues with characteristic vigor that, in his view, too many comparatists, not least many of his distinguished predecessors in the Oxford and Cambridge chairs, have been unduly academic in their work: "one also gets from the writings of these authors . . . the ... impression [that] . . the author is mainly addressing a small circle of acolytes, academics of the purist kind."17

Professor Markesinis used the occasion of the Ninth John Maurice Kelly Memorial Lecture at University College, Dublin, to be "provocative" 18 about Roman law, offering an extended advertisement for the arguments contained in Comparative Law in the Courtroom and Classroom. ${ }^{19}$ Criticizing Roman law has since become a leitmotif in his work, not least in his recent book with Professor Jörg Fedtke. ${ }^{20}$ In those books, and other recent writings which derive either their substance or their gist from them, Professor Markesinis sets out to be "deliberately controversial" 1 and to "challenge the continued utility of Roman law, arguing, instead, for the centrality of contemporary foreign law." $22 \mathrm{He}$

16 Markesinis (note 10), vii. It does not seem that Lord Phillips is using "crusade" in a pejorative sense.

17 Id., 9 .

18 B. Markesinis, "Scholarship, Reputation of Scholarship and Legacy: Provocative Reflections from a Comparatist's Point of View," Irish Jurist, 38 (2003), 1.

19 Markesinis himself concedes that his speech "naturally . . . draws in a generous but not slavish manner," before directing "the interested reader" to the book, which was shortly to be published. Any interested readers can rest assured that the speech offers an accurate and sufficient précis of all the points to be made in the book.

20 Markesinis with Fedtke (note 11).

21 Markesinis (note 10), xiv.

22 Id., xii. 
identifies Roman law as his "bête noire," ${ }^{23}$ and claims that while there is life in comparative law, "no amount of nostalgia can revive a dead language." ${ }^{24}$ Requiescas in pace, Ulpiane.

According to Markesinis, the development of comparative law as a discipline was harmed by being prevented "from turning its attention to contemporary, practical issues rather than cultivating assiduously an air of excessive intellectuality and separateness and boxing itself into a corner. For Roman law, the consequence had to be gradual atrophy." ${ }^{25}$ In his book and lecture, he criticizes, for failing to make sufficient impact with their comparative efforts, many of the leading scholars of the last century: Professors Nicholas, Rudden, Bell, J. A. Jolowicz, and Honoré. In particular, Markesinis takes issue with a previous Kelly Memorial Lecture, that of Birks, which was entitled "Hubris and Harassment: The Right to an Equality of Respect."26

It will be apparent that Markesinis's views on the use of Roman law are strident. In a review ${ }^{27}$ of the book, Sir Jack Beatson offers several counterarguments to the arguments contained in Comparative Law in the Courtroom and Classroom, which need not be rehearsed here. Beatson rightly identifies Roman Law as "the intellectual parent of Comparative Law," 28 while Tony Weir has referred to "Romanists and their confrères in comparative law and legal history." 29 What is more, in the Foreword to a book edited by Markesinis entitled Law Making, Law Finding and Law Shaping, ${ }^{30}$ Lord Bingham of Cornhill states that the book is aimed at "those with open, receptive minds, prepared to profit

23 B. Markesinis, "Understanding American Law by Looking at it through Foreign Eyes: Towards a Wider Theory for the Study and Use of Foreign Law," Tul. L. Rev., 81 (2006), 148.

24 Markesinis (note 10), 59.

25 Id., 56.

26 P. Birks, "Hubris and Harassment: The Right to an Equality of Respect," Irish Jurist, 32 (1997), 1. In this lecture, Birks sought "to encourage an interpretative recognition in the common law of the Roman delict of iniuria" and to consider the common law's position "in relation to ... another's right to an equality of respect." Id., 1 n. $\left({ }^{*}\right)$. Some of the lecture's substance was somewhat overtaken by the time of its publication in the Irish Jurist by cases and the enactment of the Protection from Harassment Act, 1997.

27 J. Beatson, reviewing B. Markesinis, Comparative Law in the Courtroom and Classroom (2003), Law Q. Rev., 120 (2004), 175.

28 Id., 179.

29 T. Weir, "Foreword," in R. Zimmermann, The Law of Obligations: Roman Foundations of the Civilian Tradition (Oxford 1996), vi.

30 B. Markesinis, ed., Law Making, Law Finding and Law Shaping [Clifford Chance Lectures, 2] (Oxford 1997). 
from the learning and experience of others, willing to judge arguments on their rational strength and conformity with principle, not their source or country of origin." 31 With that in mind, one should have thought that the use of Roman law could, at least in principle, be as valid as any other comparative reference.

\section{B. Birks's Lament}

"The revival of academic interest in taxonomy is one of Peter Birks' most significant achievements and a key element of his distinguished legacy." ${ }^{2}$ As noted above, Birks insisted on the importance of correctly identifying and classifying aspects of law, especially in modern legal education: "Our lawyers need to know more law, and they need to organize it more rationally. The rational overview and internal organization of the parts hang together. They are two parts of one taxonomic exercise."33 An intellectual heir of Gaius, he was convinced that Roman law offered much to the modern English lawyer: for Birks, "classical" meant "law that is ordered, detailed, scientific, restrained - and best." 34

It is therefore entirely appropriate that the superlative collections of essays dedicated to his memory should be entitled Mapping the Law $w^{35}$ and Structure and Justification in Private Law ${ }^{36}$ as he demonstrated that taxonomy matters. ${ }^{37}$ The latter collection contains several essays which reflect upon Birks's faith in taxonomy: for Professor Mitchell McInnes, "the real problem with Birks' taxonomy is not that its application results in error, but rather that it has not been applied with sufficient frequency and

31 Id., v, vi (Foreword).

32 H. Dagan, "Legal Realism and the Taxonomy of Private Law," in C. Rickett and R. Grantham, eds., Structure and Justification in Private Law (Oxford and Portland 2008), 147. See also E. Sherwin, "Legal Positivism and the Taxonomy of Private Law" in the same collection, and K. F. K. Low, "The Use and Abuse of Taxonomy," Legal Stud., 29 (2009), 355, especially at $368-75$.

33 P. B. H. Birks, "More Logic and Less Experience: The Difference between Scots Law and English Law," in D. L. Carey Miller and R. Zimmermann, eds., The Civilian Tradition and Scots Law: Aberdeen Quincentenary Essays (Berlin 1997), 189.

34 P. Birks, "English and Roman Learning in Moses v Macferlan," Current Legal Probs., 37 (1984), 1 (J. A. C. Thomas Memorial Lecture).

35 A. Burrows and A. Rodger, eds., Mapping the Law: Essays in Memory of Peter Birks (Oxford 2006).

36 C. Rickett and R. Grantham, eds., Structure and Justification in Private Law (Oxford and Portland 2008).

37 See most recently, E. Descheemaeker, The Division of Wrongs: A Historical Comparative Study (Oxford 2009), particularly 216-18. 
rigor." ${ }^{3}$ In the House of Lords, Lord Steyn recognized the value of a vigorous approach to taxonomy in the seminal case of Attorney General v. Blake, ${ }^{39}$ when he began his speech by observing: "My Lords, in law classification is important. Asking the right questions in the right order reduces the risk of wrong decisions." ${ }^{40}$

In his later writings, Birks lamented that Roman law was no longer regarded as important in the English law school curriculum. For him, Roman law served as a useful introduction. "So long as the basic Roman law course remained in place, English lawyers were never left without a map .... In throwing out Roman law, the law schools of common law jurisdictions have failed to think through the various goods that that study was doing." ${ }^{41}$ That is not to say that it should be argued that the Roman taxonomy itself should inevitably or invariably be adopted, but reference to it brings clarity and encourages deeper thinking about the classifications which we are to make. A skilled cartographer can draw new maps, as well as reproduce existing ones. $^{42}$

38 M. McInnes, "Taxonomic Lessons for the Supreme Court of Canada," in C. Rickett and R. Grantham, eds., Structure and Justification in Private Law (Oxford and Portland 2008), 83.

39 [2001] 1 A.C. 268.

40 Id., 290.

41 P. Birks, "This Heap of Good Learning: The Jurist in the Common Law Tradition," in B. Markesinis, ed., Law Making, Law Finding and Law Shaping [Clifford Chance Lectures, 2] (Oxford 1997), 136.

42 McInnes invokes the support of Blackstone (W. Blackstone, Commentaries on the Law of England (London 2001), para. 31):

[A]n academical expounder of the laws . . . should consider his course as a general map of the law, marking out the shape of the country, its connections and boundaries, its greater divisions and principal cities: it is not his business to describe minutely the subordinate limits, or to fix the longitude or latitude of every conceivable hamlet.

McInnes (note 38), 80. Cf. H. Dagan, "Legal Realism and the Taxonomy of Private Law," in C. Rickett and R. Grantham, eds., Structure and Justification in Private Law (Oxford and Portland 2008), 147, particularly at 154-60. At 155, Dagan argues that

the analogy of legal taxonomy to cartography is mistaken and even misleading. Cartography assumes stability in the geographical features to be mapped; it implies that there is "a fixed and immutable topography 'out there' waiting to be accurately charted." But the law is constantly changing.

(Dagan is quoting G. Samuel, "Can the Common Law Be Mapped?," U. Toronto L.J., 55 (2005), 295.) See also McInnes (note 38), 83: 
Birks was not afraid to criticize reference to Roman law where it was not helpful. For example, he staunchly opposed the common law adoption of quasi-contract, criticizing the use of "the words quasi ex contractu themselves with their eternally dangerous tendency to go round from 'as though upon a contract' (when there is none) to 'upon a sort-of-contract'." 43

Reading "Roman Law in Twentieth-Century Britain," ${ }^{44}$ one cannot but feel Birks's sense of hurt that Oxford should take the decision to render Roman law no longer compulsory as a first-year subject while he, then Regius Professor of Civil Law, was on sabbatical. ${ }^{45}$ He did concede that perhaps some of the leading Romanists could have done more to demonstrate the importance of the subject, but he noted that David Daube, for example, "probably gave no thought at all to the need to demonstrate the utility of Roman law as an introduction to law, or to the necessity of defending its place in a crowded syllabus." 46 Birks himself was acutely aware of both this need and necessity. It is interesting that both Markesinis and Birks refer to questioning the "utility of Roman law." If one sets aside the "hubristic harassment" of other scholars, there is enough substance to Markesinis's argument that we must take his crusade seriously. This paper will seek to engage with his challenge and, drawing inspiration from Birks, to illustrate the utility of Roman law.

\section{Mapping the Borders}

It may be objected that it is one thing for an academic to make some reference to the Roman position when developing his approach to private law theory at a high level of abstraction, but quite another for a barrister to cite it or, still further, for a judge to refer to it in the course of the judgment. In an interesting

Academic freedom and diversity of opinion make it difficult for a faculty as a whole to agree upon the need for, let alone the selection of, a map of the legal landscape.

43 Birks (note 34), 13. See also P. Birks and G. McLeod, "The Implied Contract Theory of Quasi-Contract: Civilian Opinion Current in the Century before Blackstone," Oxford J. Legal Stud., 6 (1986), 46.

${ }_{4}$ P. Birks, "Roman Law in Twentieth-Century Britain," in J. Beatson and R. Zimmermann, eds., Jurists Uprooted: German-Speaking Émigré Lawyers in Twentieth-Century Britain (Oxford 2004), 249.

45 The course has since been reinstated: see Section VIII below.

46 Birks (note 44), 266. 
article in the Law Quarterly Review, ${ }^{47}$ Lord Reed, a judge of the Inner House of the Court of Session, has suggested that it may be valuable to reflect on how and why we are using foreign law; likewise, it is useful to reflect on the use of Roman law. "Foreign law may ... be treated as an authority, as an empirical fact, or as a source of ideas; and these different uses have different implications ... . [E]lements of more than one of these uses may be present in a particular case, making the assessment of the implications a more complex exercise." 48 In the cases examined below, their Lordships treat Roman law as a source of ideas.

English Courts have recently been given guidance on the use of foreign law. The Practice Direction (Citation of Authorities) ${ }^{49}$ provides that:

9.1 Cases decided in other jurisdictions can, if properly used, be a valuable source of law in this jurisdiction. At the same time, however, such authority should not be cited without proper consideration of whether it does indeed add to the existing body of law.

It is not clear whether the opinions of the Roman jurists should count as "cases decided in other jurisdictions," but I should suggest that the same rule can logically apply to references to Roman law: it should not be cited without proper consideration of whether it adds to the existing body of law. For the House of Lords, however, the situation is somewhat complicated by the Scots jurisdiction and having Scots members on the Appellate Committee: it appears that the same practice will continue with the inauguration of the Supreme Court in October 2009.50 There-

47 R. Reed, "Foreign Precedents and Judicial Reasoning: The American Debate and British Practice," Law Q. Rev., 124 (2008), 253.

48 Id., 265.

49 [2001] 1 W.L.R. 1001 (Sup. Ct.).

50 Under $\S 27(8)$ of the Constitutional Reform Act, 2005, the selection commission for appointments to the new Supreme Court must continue to "ensure that between them the judges will have knowledge of, and experience of practice in, the law of each part of the United Kingdom." The House of Lords Select Committee on the Constitutional Reform Bill noted that "there is a long-standing constitutional convention that two Law Lords are appointed from Scotland, whereas the practice of appointing a Law Lord from the [sic] Northern Ireland is much more recent and less well-established." House of Lords, Select Committee on Constitutional Reform Bill, First Report, June 24, 2004, para. 166. The Committee recommended, and it is to be assumed, that this convention should continue, without express statutory recognition: id., para. 171. I am grateful to Prof. Andrew Le Sueur for this reference. 
fore, although a Roman edifice, Hadrian's Wall, divided England and Scotland, Roman learning was not prevented from influencing English law. Professor Evans-Jones has done valuable work on the relationship between Roman and Scots law, and the relationship between Scots and English law. ${ }^{51}$ His work makes clear that the mixed heritage of the House of Lords is an important consideration and impacts not only on Scots law but also English law: Donoghue v. Stevenson, ${ }^{52}$ after all, was a Scots appeal. In Birks's view, the Scots' continued loyalty to the Roman scheme offered guidance for the English system: "Scots law could still provide the map which might save English law from breaking up into a storm of disorder." 53

John W. Cairns and Paul du Plessis have recently produced a valuable study of the recent use of Roman law in Scots decisions. ${ }^{54}$ What is interesting about each of the English cases to be considered here, however, is that they do not, explicitly at least, draw on Roman law through Scots law, but go straight for the source. Birks and McLeod have it: "In England and America it is more a question of keeping alert to borrowings and avoiding explanations which are blind to the Roman learning which is always in the background." 55 In that spirit of vigilance, we shall therefore seek here to reflect on the English practice.

\section{Causation in Tort: Fairchild v. Glenhaven Funeral Services}

The Roman learning of Lord Rodger was constructive in Fairchild $v$. Glenhaven, a case concerned with exceptions to the "but for" test of causation in negligence in a situation where, due to an evidentiary gap, the claimant is unable to identify which of several tortfeasors had caused their harm. As we shall see below, causation was also an issue in Foskett.

At paragraph 27, Lord Bingham notes that Markesinis described shooting incidents as the "classic illustration" of the

51 See R. Evans-Jones, "Receptions of Law, Mixed Legal Systems and the Myth of the Genius of Scots Private Law," Law Q. Rev., 114 (1998), 228, and "Roman Law in Scotland and England and the Development of One Law for Britain," Law Q. Rev., 115 (1999), 605, the latter drawing on A. Rodger, "Lord Macmillan's Speech in Donoghue v Stevenson," Law Q. Rev., 108 (1992), 236.

521932 A.C. 562.

53 Birks (note 33), 190.

54 J. W. Cairns and P. du Plessis, "Ten Years of Roman Law in Scottish Courts," Scots L. Times, 29 (2008), 191.

55 P. Birks and G. McLeod, eds., Justinian's Institutes (London and Ithaca 1987), 7 (Introduction). 
evidentiary gap problem. Let us therefore take the, unoriginal but helpful, "two hunters" scenario as our example. A is out hunting in the forest. Two other hunters $\mathrm{B}$ and $\mathrm{C}$ both at the same time negligently shoot in the direction of A, who is killed. A is hit in the head by a single bullet, and it is impossible to determine whether it was from B's or C's gun. So there is a difficulty again for A's widow. We know that it was either B or C who killed her husband, but it cannot be proved either way. But it is clearly unsatisfactory if both B and C get away with it: so what is to be done?

In Fairchild, the claimants had contracted mesothelioma through exposure to asbestos in the course of their working lives. Scientific knowledge was such that it was not possible to determine how the mesothelioma was caused:

[T] he condition may be caused by a single fibre, or a few fibres, or many fibres: medical opinion holds none of these possibilities to be more probable than any other, and the condition once caused is not aggravated by further exposure ... There is no way of identifying, even on a balance of probabilities, the source of the fibre or fibres which initiated the genetic process which culminated in the malignant tumour. ${ }^{56}$

Mesothelioma, unlike asbestosis, the other major illness caused by asbestos exposure, is not a cumulative injury. Where, then, as in Fairchild, the claimant had contracted mesothelioma but had worked for more than one employer, there was a difficulty. To make out a claim in negligence, they had to establish that the defendant had breached a duty of care owed to the claimant, and that that breach had caused them damage. To satisfy the element of causation, the causa sine qua non test is applied: "But for the defendant's breach, would the claimant have suffered this injury?"57 The nature of mesothelioma dictated that claimants in Fairchild could not prove on the balance of probabilities that any one employer had exposed them to the asbestos fiber which had caused their mesothelioma: it could have been one of their other

56 Fairchild (note 5), para. 7 (per Lord Bingham). For a detailed account of the consequences of asbestos exposure, see J. M. Parsons, "Asbestos Related Disease Claims - A Continuing Cause for Concern in the 1990s and Beyond?," J. Personal Injury L., (1997), 5. The article predates the Fairchild decision, but anticipates the difficulties posed by mesothelioma claims.

57 Barnett v. Chelsea and Kensington Hospital Mgmt. Comm., [1969] 1 Q.B. 428. 
employers. This point raised a difficulty if the claimant was, by the time the disease manifested itself, only able to identify one solvent defendant. The question for the House of Lords was whether, in the special circumstances of the case, an exception to the ordinary rules of causation should be recognized. The House was unanimous ${ }^{58}$ in answering that question in the affirmative.

In his judgment, Lord Rodger displayed his "predictable mastery of Roman law," 59 offering an exposition of the relevant juristic opinions, ${ }^{60}$ referring to the apparently conflicting views of the jurists Ulpian and Julian, and citing (and this would be important for Markesinis's measure of scholarship) an article on the point by Jeroen S. Kortmann. ${ }^{61}$ There seems to have been disagreement between Julian and the other jurists as to liability. The debate, as Lord Rodger explains, occurs in the context of a discussion of the situation where a slave ${ }^{62}$ has been mortally wounded by one wrongdoer but subsequently dies from an injury by a second wrongdoer. Julian held that more than one assailant could be liable for killing, whereas the general rule, from Celsus and Ulpian, seems to have been that any prior assailants were liable only for wounding. But Julian does appear to mention another situation, at D.9.2.51.1: Idque est consequens auctoritati veterum, qui, cum a pluribus idem servus ita vulneratus esset, ut non appareret cuius ictu perisset, omnes lege Aquilia teneri iudicaverunt. Using, as Lord Rodger does, ${ }^{63}$ the translation in Munro's Digest, Julian states:

This is in keeping with the view handed down from the old lawyers, who, where the same slave was wounded by several persons under such circumstances that it did not appear by

58 Lord Bingham of Cornhill, Lord Nicholls of Birkenhead, Lord Hoffmann, Lord Hutton, and Lord Rodger of Earlsferry. The author has argued elsewhere that, as subsequent decisions have shown, although the House was unanimous in Fairchild, they were not univocal: see J. Lee, "Fidelity in Interpretation: Lord Hoffmann and the Adventure of the Empty House," Legal Studies, 28 (2008), 1, particularly at 12-18.

59 P. Giliker, reviewing E. Örücü, The Enigma of Comparative Law: Variations on a Theme for the Twenty-First Century and Methodology of Comparative Law (2004), Int'l \& Comp. L.Q., 55 (2006), 244.

60 Fairchild (note 5), paras. 157-60.

61 J. S. Kortmann, "Ab alio ictu(s): Misconceptions about Julian's View of Causation," J. Legal Hist., 20 (1999), 95.

62 The discussion is on liability under the first chapter of the lex Aquilia for killing another's slaves or animals of the class of cattle. There was no liability under the lex Aquilia for killing a free man.

63 Fairchild (note 5), para. 158. 
whose hand it was that he died, came to the conclusion that they were all liable [under the lex Aquilia]. ${ }^{64}$

Although, in Fairchild, the claimants may well not have been "wounded" by another of their employers, they were at least able to show a breach of duty. ${ }^{65}$ In such a situation, Julian believed that they should be able to recover from a wrongdoer. ${ }^{66}$ Kortmann therefore argues that Julian was considering an evidentiary gaps case. ${ }^{67}$ Lord Rodger concludes his analysis by taking from his discussion

the clear implication that classical Roman jurists of the greatest distinction saw the need for the law to deal specially with the situation where it was impossible to ascertain the identity of the actual killer among a number of wrongdoers. If strict proof of causation were required, the plaintiff would be deprived of his remedy in damages for the death of his slave. In that situation, some jurists at least were prepared, exceptionally, to hold all of the wrongdoers liable and so afford a remedy to the owner whose slave had been killed. ${ }^{68}$

In his Blackstone Lecture on Causation, Lord Hoffmann gave a rather more matter-of-fact account of the use of Roman law in Fairchild:

The House was faced with a problem which, as my colleague Lord Rodger of Earlsferry demonstrated, has puzzled lawyers since Roman times: how do you deal with a case in which it is

64 C. H. Monro, trans., The Digest of Justinian, 2 (Cambridge 1909), 140-41. Lord Rodger adds the words in square brackets.

65 Brett v. University of Reading, 2007 E.W.C.A. Civ. 88, makes clear that the generosity of the Fairchild approach does not extend beyond allowing the claimant to jump the evidentiary gap when proving causation: "In a case such as this, Fairchild exceptionally relieves a claimant who has proved exposure and breach of duty from having to prove causation. What it does not do is to relieve him from proving the other elements.” Id., para. 26 (per Maurice Kay, L.J.), agreeing with Sedley, L.J.

66 It might be objected that, since they are not shown to have caused damage, the defendants in Fairchild should not be labelled wrongdoers, as that is to anticipate the result. But this point may be circular on both sides. In the Roman examples, the defendants would have been liable under the third chapter of the lex Aquilia, for causing damage short of death.

67 "Unless they had qualified forensic pathologists in Rome, it would have been quite impossible to say who killed the slave. There would have been an evidentiary problem, creating factual uncertainty about the cause of death." Kortmann (note 61), 100.

68 Fairchild (note 5), para. 160. 
clear that the harm was inflicted by one of two or more people who were all behaving unlawfully, but you cannot tell which one caused the harm. The answer given by the Roman jurists was that you hold them all liable and let them sort out the apportionment of liability between themselves. And that was the answer we gave. ${ }^{69}$

In Fairchild, Lord Bingham observed:

The problem of attributing legal responsibility where a victim has suffered a legal wrong but cannot show which of several possible candidates (all in breach of duty) is the culprit who has caused him harm is one that has vexed jurists in many parts of the world for many years . . . . It is indeed a universal problem calling for some consideration by the House, however superficially, of the response to it in other jurisdictions. ${ }^{70}$

Lord Bingham here touches on a key reason as to why judges, academics and students can find comparative law valuable, which is the universality, and, crucially, the perenniality, of many legal problems. Lord Rodger's exposition of the Roman law demonstrates, just as the two hunters scenario does, that the evidentiary gap issue is not confined to asbestos-related mesothelioma claims. The question is whether it is consistent with principle to allow a policy-based exception for cases exhibiting this type of difficulty; it should not be a political decision to allow recovery in the particular industrial disease case before the court. Sadly, this is a feature which was lost on Parliament, when, in immediate response to the subsequent decision of the House in Barker $v$. Corus, ${ }^{71}$ the Compensation Bill was amended, as stated in the Preamble, "to make provision about damages for mesothelioma." Section 3(1)(a) and (b) make clear that the provision is even more narrowly limited to asbestos-related mesothelioma. Yet, due to the nature of the common law and the generality of the evidentiary gap problem, Barker will continue to apply to all situations outside of the narrow statutory enclave.

Markesinis has repeatedly referred ${ }^{72}$ to Fairchild as an example of judicial use of comparative materials, arguing that it "must

69 L. Hoffmann, “Causation," Law Q. Rev., 121 (2005), 599.

70 Fairchild (note 5), para. 23.

712006 U.K.H.L. 20.

72 B. Markesinis and J. Fedtke, "The Judge as Comparatist," Tul. L. Rev., 80 (2005), 13. The authors view Fairchild as an appropriate case for comparative dialogue because it is an example of "when a problem is 
surely mark a kind of high water mark in the use of foreign law by the highest court of the land."73 It should be noted that not all comparatists share Markesinis's view of the use of comparative materials in Fairchild. Professor Giliker has argued:

[I]t is surely important to question more carefully how cases such as Fairchild $v$ Glenhaven Funeral Services Ltd utilize comparative analysis and whether, in fact, it is being used as "second nature" as a "significant interpretative tool" . . . . [D]espite reference to ten different civil or mixed systems, Lord Bingham is dependant [sic] on extracts from secondary sources, rendering his analysis by its very nature derivative. $^{74}$

We shall return to this point below, but for now let us assume that Markesinis's analysis is correct. Of course, when considering the German law position, both counsel and their Lordships made several references to Professor Markesinis's works on that area. In Markesinis's consideration of the case, his focus is on the use of modern materials, although he concedes in a footnote that

Roman law texts were also cited by Sir Sidney Kentridge QC, counsel for the claimants, but that is understandable given that his origins and most of his career was South African, as well as the fact that he was addressing one judge - Lord Rodger - who is a champion of Roman law. It is, however, also noteworthy that Lord Rodger, while citing the Roman law material, was also quick to switch his main attention to the German material which he admitted was "more instructive."75

With respect, it strikes me as somewhat odd that Professor Markesinis is so ready to dismiss the use of Roman law. We might equally note that it is understandable that he, as one of the counsel for the plaintiffs in White $v$. Jones, ${ }^{76}$ should refer to

geographically wide-spread and it is desirable to have a harmonised response." Id., 94.

73 Markesinis (note 10), 212.

74 Giliker (note 59), 244.

75 Markesinis and Fedtke (note 72), 96 n.279 (reference omitted). See also Markesinis (note 18), 19: "[W]ith the greatest respect to the learned law lord, how does it help a modern practitioner to be told that the problem they are asked to solve had begun to exercise minds of the Roman jurists not later than the first century BC?" As to an answer to this objection, see Section VII below.

76 [1995] 2 A.C. 207. 
comparative materials, given that, as his work regularly demonstrates, he is one of the leading comparative law scholars of recent decades.

Indeed, Lord Goff makes this point in his piece in a book edited by Markesinis himself. 77 Lord Goff tells of an encounter with a young English Q.C., shortly after judgment was handed down in White v. Jones, where he was greeted with "Hullo Lord Goff; I see that in future we have got to provide you with all the relevant German authorities as well as all the English authorities."78 Lord Goff continues:

[T] he lawyers acting for the disappointed legatees instructed Basil (Markesinis) as one of their Counsel, so that they were able to place all [the German] material before the Appellate Committee. It so happened that I knew it already; but this at least meant that counsel on the other side had the opportunity to comment on it. ${ }^{79}$

The implicit accusation made by Markesinis above, that Sir Sidney Kentridge Q.C. was simply offering information which he knew would be persuasive to one judge on the Committee, is one which may be leveled at Markesinis himself. Lord Goff has been one of the leading advocates of the use of comparative materials in the House of Lords. But such an approach is not necessarily a bad thing: indeed, it is consistent with the Markesinis approach to packaging. As Dworkin has noted, in a civil case, "the difference between dignity and ruin may turn on a single argument that might not have struck another judge so forcefully, or even the same judge on another day." 80

Furthermore, it must be noted that Lord Rodger's observation on the German law being "instructive" followed a reference to the French law, several paragraphs after his discussion of Roman law:

The Commonwealth cases were supplemented, at your Lordships' suggestion, by a certain amount of material describing the position in European legal systems. Again I do not repeat Lord Bingham of Cornhill's survey. The material provides a check, from outside the common law world, that

77 R. Goff, "Comparative Law: The Challenge to the Judges," in B. Markesinis, ed., Law Making, Law Finding and Law Shaping [Clifford Chance Lectures, 2] (Oxford 1997), 37-41.

78 Id., 39.

79 Id.

80 R. Dworkin, Law's Empire (London 1986), 1. 
the problem identified in these appeals is genuine and is one that requires to be remedied.

So, for instance, the French courts have been particularly exercised by cases, similar to Cook $v$ Lewis, arising out of hunting accidents where the victim is unable to pinpoint which of a group of huntsmen caused his injury. The law has permitted the victim to recover damages, partly at least by finding that the substantial cause of the victim's injury was some negligence or recklessness of the group as a whole. The decision of the Second Chamber of the Cour de Cassation in Litzinger c Kintzler D 1957493 note Savatier is an early example. I refer to the discussion in van Gerven, Lever \& Larouche: Cases, Materials and Text on National, Supranational and International Tort Law (2000), pp 442-444.

The German position is even more instructive. Since its inception, article 830(1) second sentence of the Bürgerliches Gesetzbuch has contained a special provision which in effect provides that, where it cannot be ascertained which of a number of individual wrongdoers caused the victim's injury, each of them is to be held liable . . . 81

It is therefore clear that Lord Rodger was not suggesting that the Roman law position was not helpful, and the full quote that the German position is "even more instructive" underlines that he still viewed all the other comparative material as valuable.

The charge leveled at Fairchild is that it is an example of what Cairns and du Plessis have identified as the "so-called 'Rodger effect',"82 that counsel will cite Roman material because of Lord Rodger's distinction as a Roman scholar. For his part, Lord Rodger is not so naïve as to be unaware of this tendency, and he does not suggest that reference to Roman law is invariably sensible or helpful: in his own John Kelly Memorial Lecture (the first), his Lordship was somewhat skeptical about the use made of some comparative law. "[N]othing is gained by simply quoting chunks of law from other jurisdictions: they can be really useful only as an aid to the proper analysis of the question before the court." 83 The two cases to which we shall now turn did not involve Lord Rodger.

In any case, it is impossible to read Fairchild and fail to conclude that the comparative material, and in that I include both

81 Fairchild (note 5), paras. 165-67 (emphasis added).

82 Cairns and du Plessis (note 54), 193.

83 A. Rodger, "Savigny in the Strand," Irish Jurist, 28-30 (1993-95), 18. 
the German and Roman law, provided the court with great assistance in reaching a result to a problem which, as Lord Rodger recognized, could not be resolved by the "mere application of common sense." 84

\section{Property and Unjust Enrichment: Foskett v. McKeown}

Foskett v. McKeown concerned the misuse of a trust fund and the facts read like a finals examination problem. Mr. Murphy was a trustee of money provided for the purchase of holiday properties in Portugal. He had taken out a life insurance policy, and, having paid at least the first two premiums with his own money, he then misappropriated some $£ 20,440$ of the fund to pay two of the annual premiums. ${ }^{85}$ Crucially, the terms of the policy ${ }^{86}$ provided that the lump sum was payable after at least two premiums had been paid, as summarized by Sir Richard Scott V.-C. in the Court of Appeal in Foskett:

[I]f a premium is not paid, then (provided at least two years' premiums have been paid) the policy is converted into a paidup policy and units that have been allocated to the policy are applied annually in meeting the cost of life insurance until all the allocated units have been used up. Only at that point will the policy lapse. ${ }^{87}$

84 Barry Nicholas, the great Romanist and former Professor of Comparative Law at Oxford, tells of a story of the famously prickly Fritz Pringsheim:

Pringsheim certainly took part in tutorial teaching. He once invited me to tea on a Sunday afternoon with his pupils, numbering about half a dozen. Otherwise I remember little. Some time later I sent him an offprint of an article that I had written. Apart from a brief acknowledgement, the text of his reply, I remember, was: "This may be good English common sense. It is not Roman law."

B. Nicholas, "German Refugees in Oxford - Some Personal Recollections," in J. Beatson and R. Zimmermann, eds., Jurists Uprooted: GermanSpeaking Émigré Lawyers in Twentieth-Century Britain (Oxford 2004), 747 (original emphasis).

85 There were five premiums in total, and there was some dispute between the parties as to the extent to which the third (middle) premium was paid out of the purchasers' money, but this point is not material here, as the appeal to the Lords was conducted on the basis that the final two payments were in issue, with the question of the third premium left to be decided on the facts.

86 Conditions $1(\mathrm{e}), 6$, and 10.

87 Foskett v. McKeown, 1998 Ch. 265, 275. 
Mr. Murphy later committed suicide and the insurance company paid out on the policy to his children. The sum paid out was one million pounds. An added complication was that, under the policy, the sum was liable to be paid out after the first two payments, which were not paid with misappropriated moneys. After the fraud came to light, the purchasers (the beneficiaries under the original trust) sought a remedy. The question was whether the purchasers were entitled to recover only the amount of money which had been misappropriated or a proportionate share of the proceeds of the policy. As Lord Browne-Wilkinson put it, "[t]his case, unusually, raises the . . question: which of two innocent parties is to benefit from the activities of the fraudster." 88

The majority, led by Lord Millett, held that "the plaintiffs seek to vindicate their property rights, not to reverse unjust enrichment," 89 and therefore the plaintiffs were able to recover a proportionate share of the proceeds of the policy. Lords Millett and Hoffmann both saw the case as a textbook or straightforward case of mixed substitutions. Lords Steyn and Hope dissented. Lord Steyn ${ }^{90}$ indicated that the claimants should not have been able to recover as they could not show that the defendants had been unjustly enriched at their expense: the children were already entitled to the money before their father misappropriated the trust moneys. Further, Lord Steyn does not convey the same sense of hostility towards proprietary restitutionary rights as displayed by the majority: "If justice demanded the recognition of such a proprietary right to the policy moneys, I would have been prepared to embark on such a development." ${ }^{91}$

Foskett was therefore not an easy case. ${ }^{92}$ It was remarked

88 Foskett v. McKeown, [2001] 1 A.C. 102, 106.

89 Id., 129. See also id., 108 (per Lord Browne-Wilkinson):

The crucial factor in this case is to appreciate that the purchasers are claiming a proprietary interest in the policy moneys . . . Nor is the purchasers' claim based on unjust enrichment. It is based on the assertion by the purchasers of their equitable proprietary interest in identified property.

90 Id., 112, 115.

91 Id., 115.

92 Lord Goff dealt best with the adage that "hard cases make bad law" in his famous Maccabaean Lecture:

[A] startlingly erroneous argument can sometimes only be refuted by a re-examination, and possibly also a restatement, of fundamental legal principles. Hard cases may make bad law; but, to a remarkable degree, bad cases may also make hard law. But let there be no doubt 
above that when difficult cases arise, judges may refer back to their training. As Alan Berg has noted, ${ }^{93}$ the majority in Foskett were three former Chancery judges, while the others were not (Lord Steyn was a judge on the Queen's Bench, while Lord Hope is a Scot, but both are from mixed jurisdictions). In drawing on their learning, Lords Hoffmann and Hope resorted to Roman law to help them to grasp the issues and the concepts involved in the claim. "Ultimately, much turned on how the policy was conceptualised." ${ }^{4}$ It should be noted that, as Lord Hope mentioned, ${ }^{95}$ there was an alternative claim ventured in unjust enrichment.

But there was also a dispute between their Lordships as to how the Roman jurists would have analysed the claim. In delivering a short concurring speech, Lord Hoffmann stated:

[T] his is a straightforward case of mixed substitution (what the Roman lawyers, if they had had an economy which required tracing through bank accounts, would have called confusio) .... This [claim] is not based upon unjust enrichment except in the most trivial sense of that expression. It is . . a vindication of proprietary right. ${ }^{96}$

Lord Hoffmann here falls back on his Roman learning to approach what is a difficult problem. But in invoking the concept of confusio, his Lordship is also seeking to fortify the majority's argument that this is a relatively simple claim for vindication of property rights. It is an attempt to reduce the problem to first principles. A confusio was the Roman term for the mixtures of goods in such a way that it was not readily reversible. On this view, in Foskett, the question is simply what happens when two people's money has been mixed in such a way that it cannot be reversed.

Lord Hope, on the other hand, disagreed. In his view, the claim is more difficult than the straightforward vindication of a property right. Not only, therefore, does he challenge the major-

about it: as we perform this forensic exercise, we are using facts to develop principles.

R. Goff, "The Search for Principle," Proc. Brit. Acad., 69 (1984), 183.

93 A. Berg, "Permitting a Trustee to Retain a Profit," Law Q. Rev., 117 (2001), 366-67.

94 C. Rotherham, "Trust Property and Unjust Enrichment: Tracing into the Proceeds of Life Insurance Policies," Cambridge L.J., 59 (2000), 443. For a helpful exploration of the possibility of different legal analyses of the same factual situation, see G. Samuel, "Ex facto ius oritur," Civ. Just. Q., 8 (1989), 53.

${ }_{95}$ Foskett (note 88), 125.

96 Id., 115. 
ity's view of the English law, but he also takes issue with Lord Hoffmann's explanation of the Roman law. The problem is actually quite difficult, and Lord Hope thinks that the jurists would have found it difficult too:

Problems relating to rights arising out of payments made by the insurers under the policy would have belonged in Roman law to the law of obligations, and it is likely that the remedy would have been found in the application of an appropriate condictio. ${ }^{97}$

Lord Hope saw the conditional clause in Lord Hoffmann's observation as crucial: the Romans did not have an economy which required tracing through bank accounts. In general, the doctrine of confusio related to corporeal property, not incorporeal property. ${ }^{98}$ Furthermore, there is some doubt as to whether the doctrine applied to (physical) money: a passage from Iavolenus ${ }^{99}$ in the Digest suggests that it did not, in a true instance of a not readily reversible mixture (si mixti essent, ita ut discerni non possent), but Buckland rightly describes the passage as "so shortened as to leave it obscure."100 Johnston ${ }^{101}$ also cites Ulpian, D.12.1.11.2 and 13 pr.-1, but it does not seem to support a general proposition about the applicability of confusio to money, although the passages may have some relevance to unjust enrichment. ${ }^{102}$

97 Id., 121, and generally, 121-22.

98 The Romans did in fact use the term confusio for incorporeal things, but in a more limited sense: where the right and liability came to vest in the same person (see, e.g., W. W. Buckland, A Text-Book of Roman Law from Augustus to Justinian, 3rd ed. rev. P. Stein (Cambridge 1963), 563-64), such as where one party was the heir (heres) of the other. Similarly, servitudes could be terminated when the same person became the dominus of both the dominant and the servient land: nemini res sua servit. D.8.6.1 (Gaius 7 ed. prov.) and J. A. C. Thomas, Textbook of Roman Law (Amsterdam 1976), 201. The same applied to a debt.

99 D.46.3.78 (Iavol. 11 ex Cass.): Si alieni nummi inscio vel invito domino soluti sunt, manent eius cuius fuerunt: si mixti essent, ita ut discerni non possent, eius fieri qui accepit in libris Gaii scriptum est, ita ut actio domino cum eo, qui dedisset, furti competeret.

100 Buckland (note 98), 209 n.2.

${ }^{101}$ D. Johnston, Roman Law in Context (Cambridge 1999), 54-55. I am grateful to Dr. David Fox for this reference.

102 In particular, the second text refers to the specific situation where a slave has lent money belonging to his master contrary to the will of his master. A condictio would lie against a third party who had consumed the money by expenditure. "Si sine dolo malo consumpsisti" would seem to suggest that no defense akin to good faith change of position was available: on the contrary, it would appear that situation determined that 
The facts of Foskett would not therefore have been regarded as a simple case of confusio. Lord Hope's reference to Roman law contrasts sharply with that of Lord Hoffmann: rather than an attempted reduction to first principles, it actually serves to illustrate the complexity of the claim. By considering the reference to Roman law, then, we can appreciate a new dimension to their Lordships' methods of argumentation in disagreement over the English position.

Yet, with some brief exceptions, ${ }^{103}$ this disagreement between their Lordships over the Roman law has gone by largely without comment. ${ }^{104}$ Their Lordships' assessment of the Roman position maps onto, and perhaps is informed by, their view of English law. Birks argued, in a piece in Current Legal Problems, that:

Lord Hoffmann seems to suggest that the event on which to focus was a physical mixture of the kind the Romans would have called a confusio .... On the facts before the House of Lords there never was any confusio, only a substitution. If I steal money and pay it into my bank, there is no mixture of money, not even if the account is in credit. The money does not go into the account. It is exchanged for a claim against the bank, evidenced by the keeping of the account. There is a substitution, not a mixture. ${ }^{105}$

That article was written around the time of Birks's change of direction concerning absence of basis, and he went on vehemently to disagree with Lord Millett, in print and in correspondence, ${ }^{106}$ as to the correct analysis of the claim. One might, therefore, think it odd that Birks did not consider Lord Hope's approach to the Roman law.

the condictio was the appropriate action to be brought, rather than the vindicatio or an actio ad exhibendum.

${ }^{103}$ P. Birks, "Property, Unjust Enrichment and Tracing," Current Legal Probs., 54 (2001), 242-43. See also P. Hood, "What is So Special About Being a Fiduciary?," Edinburgh L. Rev., 4 (2000), 324 n.99, stating simply "With respect, the better view is that of Lord Hope." Berg (note 93) also mentions it in passing, taking a dim view.

104 Although it is not concerned with Foskett, for a valuable consideration of the Roman and English positions with regard to accidental mixtures, see R. W. J. Hickey, "Dazed and Confused: Accidental Mixture of Goods and the Theory of Acquisition of Title," Mod. L. Rev., 66 (2003), 368.

105 Birks (note 103).

106 P. Millett, "Jones v Jones: Property or Unjust Enrichment?," in A. Burrows and A. Rodger, eds., Mapping the Law: Essays in Memory of Peter Birks (Oxford 2006), 265. 
However, it is here that we find a problem with the Roman taxonomy. The institutional scheme of Gaius divides private law into persons, things, and actions: Omne autem ius, quo utimur, vel ad personas pertinet vel ad res vel ad actiones. ${ }^{107}$ The law of things embraces corporeal and incorporeal things. ${ }^{108}$ Traditionally, the law of things divides into the law of property, the law of succession and the law of obligations. But this classification "conceals the fact that property rights can arise as a result of the same event that generates personal obligations."109 Furthermore, Worthington has sought to explode the English approach to property and obligations with an impressively iconoclastic article. ${ }^{110}$

So Birks's response to Foskett engaged with this issue. In Unjust Enrichment, he disagreed with the shared assumption of both the majority and minority in the Lords that there was a necessary opposition or apposition between property and unjust enrichment. He argued that "a disabling heresy as to the relationship between property and unjust enrichment has gained surprising ground. The heresy supposes, indefensibly, that property and unjust enrichment are systematically opposed categories." ${ }^{111}$ Likewise, Burrows ${ }^{112}$ has argued that the contrast between the proprietary and unjust enrichment claims is based on a fiction. Instead the focus should have been on the causality (or

107 G.1.8; also J.1.2.12.

108 G.2.12-14.

109 J. Edelman, reviewing J. Gordley, Foundations of Private Law (2006), Law Q. Rev., 124 (2008), 167.

110 S. Worthington, "The Disappearing Divide Between Property and Obligation: The Impact of Aligning Legal Analysis and Commercial Expectation," Texas Int'l L.J., 42 (2007), 917; also in S. Degeling and J. Edelman, eds., Equity in Commercial Law (Sydney 2005).

111 P. Birks, Unjust Enrichment, 2nd ed. (Oxford 2005), 204.

112 A. Burrows, "Proprietary Restitution: Unmasking Unjust Enrichment," Law Q. Rev., 117 (2001), 419:

The true position is that, in this situation, the claimant has concurrent claims; and that once the claimant has elected (and had satisfaction of) a personal claim to reverse the defendant's unjust enrichment, legal property in the enrichment passes to the defendant.

A useful analogy can be drawn with the tort of conversion. The fact that the claimant owns the property in the defendant's hands does not prevent, and on the contrary is usually a condition of, the claimant being able to recover compensatory damages; and, on satisfaction of the claim for damages, the defendant acquires legal title. 
the causative link) required by the law of unjust enrichment, and the nature of proprietary responses to unjust enrichment. ${ }^{113}$

Here, therefore, we can see that, even though they disagree, both Lord Hoffmann and Lord Hope's references to Roman law entail the assumption that the claim must either be for the vindication of a property right or for restitution of an unjust enrichment (under the law of obligations).

Another opposition to be highlighted in Foskett is that between the inspirations behind the majority's and minority's approaches. Although they are not expressly credited, the majority owes much to the work of Graham Virgo, adopting his approach to vindication of property rights, and to the joint writings of Grantham and Rickett. On the other hand, Hood has noted that Lord Hope's speech is notable for its use of "Birksian language."114 In addition, therefore, to the disagreement as to the Roman approach to the claim at hand, there is also a tacit battle between competing academic views. Given that it is not so long ago that the judges only permitted themselves to refer directly to the work of deceased academics (who were therefore not able to answer back) we should perhaps be modest in our expectations, and judges currently are much more explicit, as the next case will show. ${ }^{115}$ References to the Roman jurists, of course, did not fall foul of the previous rule.

\section{Property and Tort: $O B G$ v. Allan}

Having considered the use of Roman law in cases where the Roman position was explored in some detail, we shall now endeavor to expand on a cursory reference to Roman law in the most recent of our three cases. $O B G v$. Allan ${ }^{116}$ was a very significant

${ }^{113}$ Id., 421-22.

${ }^{114}$ Hood (note 103).

115 In OBG v. Allan, 2007 U.K.H.L. 21 (conjoined appeal with Douglas v. Hello! Ltd., and Mainstream Props. Ltd. v. Young), on the issue of the structure of the economic torts, their Lordships were essentially choosing between various academic approaches, and they acknowledged that this was the case quite openly. Their Lordships had the benefit of Hazel Carty's An Analysis of the Economic Torts (Oxford 2001), which they largely endorsed; Tony Weir's Clarendon Law Lectures (Economic Torts (Oxford 1997)); and P. Sales and D. Stilitz, "Intentional Infliction of Harm by Unlawful Means," Law Q. Rev., 115 (1999), 411.

116 Cited in note 115 above. The panel for the appeals was Lord Hoffmann, Lord Nicholls of Birkenhead, Lord Walker of Gestingthorpe, Baroness Hale of Richmond, and Lord Brown of Eaton-under-Heywood. 
decision of the House of Lords ${ }^{117}$ on three consolidated appeals, one of which concerned the publication of the wedding photographs of Michael Douglas and Catherine Zeta-Jones. The appeals required their Lordships to consider three controversial areas of the law of torts: the structure of the economic torts, the scope of breach of confidence, and the role of conversion. At the beginning of his speech, Lord Nicholls noted: "Judicial observations are not always consistent, and academic consensus is noticeably absent. In the words of one commentator, the law is in a 'terrible mess.' So the House faces a daunting task."118

Three different issues divided the House. On the economic torts, there was much common ground as to the overall structure of the area, but Lord Nicholls of Birkenhead dissented on the issue of the scope of unlawful means. On breach of confidence, Lords Nicholls and Walker of Gestingthorpe dissented. For present purposes our focus is on the third issue, concerning the tort of conversion, which was raised in the $O B G$ appeal. The claimant company sued the defendants, invalidly appointed receivers who had disposed of the company's assets. The receivers had acted in good faith.

The company advanced various claims, succeeding in trespass to its land and conversion of its chattels. The contentious claims before the House were in economic tort, for wrongful interference with contractual relations (which the House decided was not an independent tort), and conversion of its intangible property, choses in action. Since the defendant receivers had acted in good faith, they could not be liable in the economic torts (which require intention). If, therefore, the claimant company was to recover at all for the interference with their contracts, it had to be in conversion. But the claim for conversion of the intangible property failed, as the majority held that conversion did not extend to intangible property, and should not be extended to do so. Baroness Hale of Richmond joined Lord Nicholls in dissenting on this point. We have, as in Foskett, a dispute over taxonomy: the majority and minority disagreed as to whether the true nature of the claim lay within the law of property or within the law of obligations.

${ }^{117}$ It is also, to the best of my knowledge, the longest decision of the House of Lords since the adoption of paragraphs in judgments at the start of this decade, running to 330 paragraphs: see J. Lee, "A Defence of Concurring Speeches," Public Law, (2009), 319.

$118 O B G$ (note 115 ), para. 139. 
As Baroness Hale noted, it is almost a legal cliché for judges to refer to the tort of conversion as the closest thing the common law had, and has, to the Roman vindicatio:

The common law, as is well known, lacked any general proprietary remedy equivalent to the Roman law vindicatio. It provided three separate remedies for wrongfully taking away, keeping, or disposing of another's goods: trespass, detinue and trover or conversion. Conversion had distinct procedural advantages over the other two and rapidly extended its boundaries to cover much the same ground as they did. ${ }^{119}$

It might seem that the mention of the vindicatio is a throwaway and superficial reference, but it can be argued that it goes deeper than that. Baroness Hale's reference to the vindicatio is important because it invokes an alien concept which is absent from the common law, which does not recognize absolute ownership. ${ }^{120}$ In making that reference, Baroness Hale throws the common law claim into relief: the adversion to the absence of a vindicatio requires the judges to address its absence, and to consider what the point of the tort of conversion is.

Before perusing the Roman law, it is necessary briefly to consider the development of the modern tort of conversion. ${ }^{121}$ As both

119 Id., para. 308.

${ }^{120}$ In Waverley Borough Council v. Fletcher, 1996 Q.B. 334, a case where the defendant had used a metal detector to find a gold brooch in a park unaware of the prohibition on using such devices, Auld, L.J., stated, at 345, that the "English law of ownership and possession, unlike that of Roman Law, is not a system of identifying absolute entitlement but of priority of entitlement." I am grateful to Prof. Geoffrey Samuel for this reference. Birks critically reflected on the "absolute" quality of Roman ownership, concluding that:

Roman ownership was minimally restricted. Most of the material world could be owned, and the owner's freedom to use and to alienate his property was, broadly speaking, secure and unhampered. However it was not absolutely unhampered; nor was there any legal theory to set a limit beyond which legislative interference could not go. For the content of ownership, "absolute" is not an appropriate word. It suggests some degree of immunity. Conceptually, however, ownership was absolute: distinct, singular and exclusive.

P. Birks, "The Roman Law Concept of Dominium and the Concept of Absolute Ownership," Acta Juridica, (1985), 31.

121 For a most useful assessment and restatement of the tort of conversion, see S. Douglas, "The Nature of Conversion," Cambridge L.J., 68 (2009), 198. 
Professors Tettenborn ${ }^{122}$ and Birks ${ }^{123}$ have pointed out, the subject of personal property, and indeed the very basic question of how one might go about using a legal remedy ${ }^{124}$ to recover one's personal property that someone else has, is often overlooked in the English law syllabus. "Property" is frequently treated as, and taken to mean, real property. As we saw in Foskett, equity does allow a form of vindicatio, in that one can assert one's beneficial ownership in property and ask the court to recognize it. But the common law, not recognizing dominium, does not have an action whereby one can simply say "That's mine!" Instead, the tort of conversion is relied upon in order to assert that the other person has interfered with one's right to possession of the thing.

Whilst eschewing a definition per se, Lord Nicholls (in a previous case) identified the basic features of the tort:

First, the defendant's conduct was inconsistent with the rights of the owner (or other person entitled to possession). Second, the conduct was deliberate, not accidental. Third, the conduct was so extensive an encroachment on the rights of the owner as to exclude him from use and possession of the goods. The contrast is with lesser acts of interference. If these cause damage they may give rise to claims for trespass or in negligence, but they do not constitute conversion. ${ }^{125}$

Before conversion subsumed trespass and detinue, the other two actions related to property mentioned by Baroness Hale above, to "convert" property was to dispose of it, or to otherwise treat it in a way inconsistent with another's ownership. Now, however, conversion fulfils a more general role, having taken the place of detinue, which was abolished by the Torts (Interference with Goods) Act, 1977, ${ }^{126}$ after the Law Reform Committee argued that conversion effectively performed the role of detinue. ${ }^{127}$ Simon Douglas has offered a valuable assessment of the late action of

${ }^{122}$ A. Tettenborn, reviewing S. Gleeson, Personal Property Law (1997), Lloyd's Mar. \& Com. L.Q., (1999), 586.

${ }^{123}$ P. Birks, "Personal Property: Proprietary Rights and Remedies," King's C.L.J., 11 (2000), 1-2.

${ }^{124}$ One could, of course, simply ask for it back.

${ }^{125}$ Kuwait Airways Corp. v. Iraqi Airways Co. (No. 3), 2002 U.K.H.L. 19, para. 39 .

126 Torts (Interference with Goods) Act, 1977, § 2(1).

${ }^{127}$ Law Reform Committee, "Conversion and Detinue," 1971, Cmnd. 4774 (Law Reform Com. No. 18), at 4. 
detinue, in which he convincingly argues that detinue was a tort rather than a proprietary action. ${ }^{128}$

Conversion is, therefore, multi-faceted and does the work of what were historically different torts. Indeed, as Sarah Green has it:

Conversion, as we now recognise it, has a complex pedigree. Showing little regard for received taxonomies, it has elements which make lawyers think in terms of property, despite its eventful descent from actions in personam. ${ }^{129}$

It is with the provenance of conversion in mind that we may turn to consider its relationship to the vindicatio. In $O B G$, the absence of a common law vindicatio cut both ways. For the majority, it was precisely because conversion is a tortious claim and not a proprietary claim that it does not extend to all types of property. As Birks puts it, "There is no escaping the fact that the right upon which the plaintiff stands is the personal right which correlates with the obligation to pay damages for the tort of conversion." 130 The claimant company's argument would create "a mutant tort of conversion of contracts." 131 For the minority, however, "although nominally tortious, conversion had become the remedy to protect the ownership of goods." 132 Conversion has, as Birks recognizes in the same article, an "underlying vindicatory function." 133 For Baroness Hale, "Once the law recognises something as property, the law should extend a proprietary remedy to protect it."134 But, under the present law, if someone else has your personal property and that property is a chattel, then your remedy is conversion.

It is, as Baroness Hale suggested, a commonplace that conversion does some of the work of the vindicatio, but rarely, if ever,

128 S. Douglas, "The Abolition of Detinue," Conv. \& Prop. Law., (2008), 30, especially 41-42.

${ }_{129}$ S. Green, "Can a Digitized Product be the Subject of Conversion?," Lloyd's Mar. \& Com. L.Q., (2006), 568. See also Douglas (note 121), 206:

Because the action evolved to deal with the problems of the older writs it is difficult to discern within conversion any clear policy towards the question of how property rights in chattels should be protected. It is mainly for this reason why it has proved so hard to conceptualise the modern action.

${ }^{130}$ Birks (note 123), 7.

${ }^{131}$ P. Watts, "Self-Appointed Agents - Liability in Tort," Law Q. Rev., 123 (2007), 522.

${ }_{132} O B G$ (note 115), para. 308 (per Baroness Hale).

133 Birks (note 123), 7.

${ }_{134} O B G$ (note 115), para. 310. 
do judges consider the other Roman actions which share some similarities with conversion. This may simply be due to the common law mythology of the vindicatio, or perhaps it is because the vindicatio is generally known but references to the other relevant actions would require more than a distant recollection of Roman law. ${ }^{135}$ Expanding on a suggestion that the author has made elsewhere, ${ }^{136}$ this section will therefore consider whether the vindicatio is the closest Roman comparator, or whether other actions have a claim. There are, I suggest, four particular Roman law actions worthy of scrutiny: (rei) vindicatio, actio furti, condictio (ex causa) furtiva, and possessory interdicts.

The vindicatio is straightforward enough: the "That's mine!" claim. The possessory interdict was an action in which the claimant asserted that the defendant had interfered with his possession of a thing and his remedy was to recover possession. Title was entirely irrelevant, as ownership is not the same as possession: nihil commune habet proprietas cum possessione (D.41.2.12.1, Ulpian 70 ad edictum). This was often the point: the possessory interdict was used to decide who was to be the defendant for a subsequent vindicatio if there was a property dispute. It is, of course, easier to prove possession than ownership. It was therefore to a claimant's advantage to bring the interdict first.

In a stimulating chapter on "Possession and Ownership,"137 Gordley refers to the nineteenth-century German debate over the nature of protection afforded to possession. ${ }^{138}$ Savigny drew the comparison between the vindicatio and the possessory interdicts, and argued that the interdicts were a species of tort action. Jhering disagreed with Savigny's analysis. ${ }^{139}$ It is symptomatic of

135 See Section VII below. Lord Rodger has, for example, never referred to the vindicatio in an English law case. We saw above that Lord Hope did have the chance to consider Roman proprietary/personal actions in Foskett v. McKeown.

136 J. Lee, "Restoring Confidence in the Economic Torts," Tort L. Rev., 15 (2007), 172, 175-76.

137 Gordley (note 12), ch. 3. Gordley's answer to his own question

"Why Protect Possession?" at 61-65 is particularly worth reading.

138 Id., 53-58.

139 Nicholas deals with the issue succinctly:

The main objection to Savigny is that there is no evidence that the Romans saw the distinction between possession and detention in terms of animus and corpus, and to Jhering that his explanation of the non-possession of the detentors is very forced.

B. Nicholas, An Introduction to Roman Law, rev. ed. E. Metzger (Oxford 2008), 113 n.1. 
the traditional common law approach to property that Gordley's discussion of possession takes place under the part of his book labeled "Property," focusing subsequently on land. ${ }^{140}$

If the interdicts were, at least, "tort-like," do they offer a better comparison with conversion than the vindicatio? They are similar, in that they both focus on interference with possession rather than ownership. But there are some differences: the interdict could only lie against a defendant who had dispossessed the claimant, rather than anyone interfering with the possession. The interdicts could therefore be brought only against an immediate dispossessor, whereas even a remote acquirer of stolen goods is liable for conversion.

Aside from the vindicatio and the interdicts, the Roman claimant could also seek a remedy in the law of obligations, if the property had been stolen and if he could identify the thief. These are, admittedly, two big ifs. But if we return to our core example, where someone else has my thing and I want to get it back, a simple explanation for that situation is that the other person has stolen it, though this will, of course, not always be the case. ${ }^{141}$

But, equally, the reipersecutory actions relied on the claimant still being able to identify the thing. If the thing had been lost or destroyed, the owner would have to bring the special action called the condictio. Under the condictio furtiva, the defendant was liable even if he no longer had possession. The condictio relied on the fiction that ownership passed to the thief, which Gaius explains was plane odio furum, ${ }^{142}$ "out of hatred of thieves." This odio furum encouraged the Romans not to be concerned unduly with the classification of the condictio furtiva, and Zimmermann describes the action as "[h]overing forever uneasily somewhere between the fields of delict and unjustified enrichment." ${ }^{143}$ Like

140 I should, however, endorse Edelman's conclusion that "in the context of the enormous scope of the book" such criticisms are very minor, and his assessment that "[n]o one interested in the history and theory of private law can sensibly avoid reading Foundations of Private Law." Edelman (note 109), 169.

${ }^{141}$ I do not intend to suggest that all cases of conversion are also cases of theft, as the facts of $O B G$ illustrate.

142 G.4.4.

${ }^{143}$ R. Zimmermann, The Law of Obligations (Oxford 1996), 948. Though disagreeing with his thesis, Markesinis and Fedtke offer some praise for Professor Zimmermann as a "real heavyweight" who displays "the thoroughness of the German scholar, the breadth of knowledge of a truly cultured (not just educated) man, and the messianic determination to 'save' Roman law from oblivion." Markesinis with Fedtke (note 11), 60, 306. 
the condictio, conversion lies against a converter even if he is no longer in possession of the thing.

The Roman law of furtum (theft) lay in the law of delicts and the actio furti was penal in nature, in that it was intended to punish the defendant for his dishonest conduct. Criminal sanctions for theft were not developed until the late republic, although by the time of at least Ulpian, criminal prosecutions were common. ${ }^{144}$ That delict should perform some penal function is not unusual, and, as the example of exemplary damages shows, even in the common law, "the roots of crime and tort are greatly intermingled." 145 Nevertheless, the different contexts of tort and delict must be appreciated. Under the later Roman law, a thief was required to pay four times the value of the thing for furtum manifestum (getting caught red-handed), while for all other cases, the penalty was twice the value of the thing. ${ }^{146}$

A key point of similarity between conversion and the actio furti, as opposed to the vindicatio and possessory interdicts, is the subject matter of the tort, which was the issue in $O B G$. The vindicatio and possessory interdicts were of general application and could be brought in respect of any thing, whether movable or immovable property. Conversion is, and the actio furti was, more restricted, in that neither can apply to land (or res incorporales), which reflects the traditional view of both as relating to asportation. ${ }^{147}$

Whilst beyond the scope of this paper, this common feature of conversion and the actio furti might perhaps have a consequence for the dissenting view of Lord Nicholls and Baroness Hale in $O B G$ that conversion should apply to all forms of personal prop-

144 D.47.2.93 (Ulpian 38 ed.)

145 Uren v. John Fairfax \& Son, [1966] 117 C.L.R. 118, 149 (per Windeyer, J.), quoted by the High Court of Australia in Gray v. Motor Accident Comm'n, [1998] 196 C.L.R. 1, 7 (joint judgment of Gleeson, C.J., McHugh, Gummow, and Hayne, J.J.), cited in J. Edelman, "The Meaning of 'Damages': Common Law and Equity," in A. Robertson, ed., The Law of Obligations: Connections and Boundaries (London 2004), 36.

146 Thomas (note 98), 358. Under the law of the Twelve Tables, the penalty for manifest theft was, for a freeman, scourging and enslavement, and for a slave, scourging and death. The penalty was reduced to four-fold by the praetorian actio furti manifesti.

${ }_{147}$ Nicholas (note 139), 214, opines, pithily:

Since the classical law rejected any requirement of a carrying away, the exclusion of immovables is surprising. No justification for it is offered, and some jurists thought otherwise, but their opinion did not prevail. 
erty. For, in support of the minority view in $O B G$, Green has argued that:

The essence of conversion is its protection of property interests. There is nothing other than history to tie it exclusively to a particular subject-matter. In principle, its parameters are dictated by the nature of the legal interests which it aims to protect, rather than the characteristics of the objects to which those interests relate. ${ }^{148}$

That being true, it might be raised that, on this reasoning, conversion should also apply to all forms of property. If that point is not accepted by an advocate of extending the scope of conversion, then it would seem that they accept some discrimination between types of property. That being the case, is the distinction between tangible and intangible personal property really any more arbitrary than that between real and personal property? In response, we could simply say that interests in land are not ones which the tort aims to protect. Other torts do that job: as Gordley discusses, ${ }^{149}$ the English claimant's remedy lay in ejectment or perhaps trespass to land. Likewise, as will now be clear, the Roman claimant had actions other than the actio furti available to him if he sought a remedy for being deprived of his property.

A clear point of distinction between the Roman theft actions and conversion must be recognized, however. Furtum required dishonest intent: the interference with the thing must be fraudulosa. ${ }^{150}$ Conversion, on the other hand, is a tort of strict liability, in that one can be liable even if one thinks that one is entitled to the property. So, the receivers in $O B G$, though acting in good faith, were nonetheless liable in conversion for their interference with the company's chattels. The reason for the common law approach is explained by Birks:

So long as the forms of action lasted, the plaintiff in conversion had to allege that the defendant had fraudulently and wickedly converted the things in question to his own use. As pleaded, the tort looked just like furtum, which . . . could not be committed without dishonest intent. However . . . in order

${ }^{148}$ S. Green, "To Have and to Hold? Conversion and Intangible Property," Mod. L. Rev., 71 (2008), 115.

149 Gordley (note 12), 58-59.

${ }^{150}$ See note 144 above. "Fraudulosa" is an hapax legomenon, invented by the jurist Paul to express the difficult concept of dishonesty, with which English law still struggles. See D.47.2.1.3 (Paul 39 ed.); Lee (note 58), 6-10. 
to equip the common law with a claim which could do the work of the absent vindicatio, the allegations of fraud were made untraversable. ${ }^{151}$

By contrast, the actio furti, being purely penal, was expressly envisaged to work alongside the reipersecutory actions: the owner had other "means of restoring his wealth." 152 He could elect to sue for the thing itself under the vindicatio or for its value under the condictio. The common law has only conversion. It was noted above that the Torts (Interference with Goods) Act, 1977, established that conversion had enveloped (or at least covered virtually the same ground as) detinue. But there is also statutory recognition of conversion's several functions when it comes to remedies. Where the Roman chose his action according to his desired remedy, the Englishman must rely on conversion. Section 3(2) of the 1977 Act recognizes three forms of relief:

(a) an order for delivery of the goods, and for payment of any consequential damages, or

(b) an order for delivery of the goods, but giving the defendant the alternative of paying damages by reference to the value of the goods, together in either alternative with payment of any consequential damages, or

(c) damages.

Under $\S 3(3)(\mathrm{a})$, these remedies are mutually exclusive, and $\S 3(3)(b)$ provides that relief under paragraph (a) (the new remedy of an order delivery of the goods) is at the discretion of the court. There is thus further evidence that Parliament has taken the view that conversion is something of a super-action.

Having seen such similarities as there are between the various Roman actions and conversion, we can understand better why conversion is a difficult tort: it is expected and required to do a lot of work:

The tort of conversion may be a wrong but it is a claim recognised by the law not because it can be and is logically classified as a wrong but because that is how the common law chooses to protect property rights. ${ }^{153}$

With the various functions in mind, we can now return to the question raised in $O B G$ about the future development of the tort.

151 Birks (note 123), 6 (references omitted).

152 J.4.1.19.

153 Low (note 32), 365. 
The tort of conversion can sometimes apply to intangible property. Previously, the courts extended conversion to apply to choses in action where the action was manifested in some physical form, what Baroness Hale aptly labels a "reliance on tangible tokens."154 Lord Brown justified the distinction:

I recognise, of course, that the tort has long since been extended to encompass a variety of documents, not merely documents of title and negotiable instruments but also any business document which in fact evidences some debt or obligation. But to my mind there remains a logical distinction between the wrongful taking of a document of this character and the wrongful assertion of a right to a chose in action which properly belongs to someone else. ${ }^{155}$

In comparing the Roman and English law, Nicholas has observed: "The owner only has an action in English law when he also has (as indeed he usually does have) an immediate right to possession."156 The problem raised in $O B G$ is that the owner of intangible property is an owner without possession. At present, the invalid receivers could be held liable for the conversion of some of the property, including some of the choses in action (those which have a tangible token), but not all. Thus Lord Nicholls despaired: "This distinction makes no sense. It lacks any rhyme or reason." 157 He continued: "Legal fictions, of their nature, conceal what is going on. They are a pretence."158

The intention in this section has been to consider how conversion maps onto the Roman law, to enable us to understand the point of the tort. It has not been to examine how the Romans would have analysed the problem in $O B G$, or to conclude that the Roman law necessarily offers a definitive answer. But, by going beyond the simple reference to the vindicatio, our excursive investigation of the Roman actions has shown us, it is submitted, that the modern developed tort of conversion does the work of not only the vindicatio, but of several other actions. The facts of $O B G$ illustrate that, at present, some property falls through a gap, in a way that land, as seen above, does not. We have a significant lacuna, and the present state of the law is untenable. ${ }^{159}$

\footnotetext{
${ }^{154} O B G$ (note 115$)$, para. 317.

155 Id., para. 321.

${ }^{156}$ Nicholas (note 139), 155.

$157 O B G$ (note 115), para. 221.

158 Id., para. 227.

159 Although it was not a case on private law, in R. v. Bentham, 2005 U.K.H.L. 18, para. 14, Lord Rodger offered a one-paragraph-long speech:
} 


\section{Confusio: Some Reflections}

We may use "confusio" in several different senses. Firstly, as referred to by Lord Hoffmann in Foskett, confusio was the Roman term for the accidental mixture (or joining together) of property in such a way that it was not readily reversible. ${ }^{160}$ Secondly, we may use confusio to mean confusion: in some cases it is not always clear what the relevant Roman law was, and therefore confusion may result. As the above case analyses have shown, perennial legal problems, whether on causation or the proper contours of the relationship between the laws of property and obligations, were as controversial to the Roman jurists as they are now.

This concern over confusion should not be underestimated. We have seen above that in both Fairchild and Foskett, when referring to Roman law, it was expressly conceded that the Roman jurists were not necessarily unanimous or even entirely clear in their approach. Lord Rodger said:

The exact scope of these decisions can, of course, no longer be ascertained and it is likely that different jurists held differing views: the sixth-century compilers of the Digest may well have altered the texts to some extent, if only by abbreviation, cutting out the cut and thrust of debate. Nor could the decisions, as recorded, furnish any guidance on the formulation of any equivalent rule today. ${ }^{161}$

This inherent controversiality is a feature of the law, but it may be a danger if the court is misled. ${ }^{162}$ Indeed, Markesinis

Dominus membrorum suorum nemo videtur: no-one is to be regarded as the owner of his own limbs, says Ulpian in D.9.2.13. pr. Equally, we may be sure, no-one is to be regarded as being in possession of his own limbs. The Crown argument, however, depends on the contrary, untenable, proposition that, when carrying out the robbery, the appellant had his own fingers in his possession in terms of section 17(2) of the Firearms Act 1968. I agree with my noble and learned friend, Lord Bingham of Cornhill, that for this reason the appeal should be allowed.

I suspect that Lord Rodger's use of "untenable" is a deliberate pun. The same passage from Ulpian was cited by the Court of Appeal in Jonathan Yearworth \& Ors v. North Bristol NHS Trust, 2009 E.W.C.A. Civ. 37, para. 30: see below at text to notes 185 to 187 .

160 Though, as noted above at text to notes 99 to 102, perhaps not for money. See generally, Buckland (note 98), 208; Hickey (note 104), 369-72.

${ }^{161}$ Fairchild (note 5), para. 160.

162 See Practice Direction (note 49) . 
concedes that in Greatorex, ${ }^{163}$ one of his favorite cases for the way in which comparative material was used in the decision,

the English court looked only at one side of German law; indeed, it could not have done more since counsel drew the judge's attention to the German decision but nothing more. The English court was thus not made aware that the German result might, in some instances, have also been reached by utilising the immunity conferred by $\S 1359$ BGB. ${ }^{164}$

Any use of Roman law may be necessarily selective, as it may be possible to discover the opinion of a jurist in favor of one's argument which is not representative of the general law. Roman law in particular offers complications because of the length of its development, from Gaius to Justinian and the role of the intervention of the interpolators. Care must be taken.

It is therefore crucial that counsel and judges are aware and articulate where there was some controversy. It might even be argued that the Practice Direction (Citation of Authorities) ${ }^{165}$ requires it, as paragraph 4 of the Introduction states that "[i]t will remain the duty of advocates to draw the attention of the court to any authority not cited by an opponent which is adverse to the case being advanced."166 Our concern therefore applies to the use of comparative law generally, albeit in a different context: the principles of Roman law are more certain, perhaps, than the concurrent development of the law in civil law jurisdictions which lack a firm doctrine of precedent. ${ }^{167}$

We have seen, throughout this paper, the tremendous evolution of English law with regard to some of the most fiendish issues in private law. It is hardly surprising if, in the several hundred years between the enactment of the lex Aquilia and Ulpian, for example, there should be some disputes over complicated ques-

163 [2000] 1 W.L.R. 1970.

164 Markesinis (note 10), 172-73, and chapter 4 ("Foreign law inspiring national law. Lessons from Greatorex $v$ Greatorex"), more or less duplicated in Cambridge L.J., 61 (2002), 386. Markesinis explains in a footnote that $\S 1359$ BGB states that "one spouse is liable to the other only if he (or she) failed to attain "the degree of care which they are accustomed to exercise in their own affairs'," the rationale being "to avoid legal disputes between persons who are in such close family relationships." Markesinis (note 10), 178 n.15.

165 Cited in note 49.

166 Id., para. 4.

${ }^{167}$ I am grateful to Prof. Paula Giliker for an observation along these lines. 
tions of causation. Felix qui potuit rerum cognoscere causas. ${ }^{168}$ As long as judges are aware of any controversy, then the danger of confusion is diminished. Lord Rodger justified his reference to Roman law in Fairchild in concluding that "[t]he point remains ... that all these centuries ago considerations of policy plainly led to a departure from what the law would usually require by way of proof of causation." 169 The references to Roman law by Lord Rodger and Lord Hope in Fairchild and Foskett respectively formed part of their Lordships' attempts to engage with the intricacies of the complex issues involved in the cases.

What of other objections to references to Roman law? It may be argued that such references are a waste of time, that it is confusing and unhelpful to refer to Roman law at all, since the relevance to modern conditions of laws developed in Roman times might be doubted. Lord Hoffmann's cursory reference to confusio in Foskett contains the condition "if they had had an economy which required tracing through bank accounts." We may call this the caveat objection. In Hourigan v. Secretary of State for Work and Pensions, ${ }^{170}$ counsel told the Court of Appeal

that social security benefits staff are not customarily concerned with divided shares in corn or oil or in the other commodities which the members of the court, drawing on their memories of the Roman law concepts of commixtio or confusio, put to her during the course of argument. In the real world of social security she said that it is the ownership of shares in a business, or a house, or money that gives rise to questions of this kind. ${ }^{171}$

There are two levels to this objection: one trite, the other more significant. The first level, which we perhaps see from counsel above, is a flippant refusal to engage with Roman law because it is assumed to be obsolete, archaic, and in Latin: what one might expect of a reluctant first-year English law student embarking on a compulsory course on the Digest and the Institutes. ${ }^{172}$

168 Verg. G. 2.490 ("Fortunate was the man who could understand the causes of things.").

${ }^{169}$ Fairchild (note 5), para. 160.

1702002 E.W.C.A. Civ. 1890, [2003] 3 All E.R. 924.

${ }^{171}$ Id., para. 20 (per Brooke, L.J.).

172 See, e.g., Markesinis with Fedtke (note 11), 12-13, especially where they claim that "[references to Roman law] only helped distance their authors and their ideas slowly but steadily from the real world of practice which, particularly in the common law world, is the bloodline of survival and regeneration." 
A related but more important point is the recognition by Brooke, L.J., that their Lordships were "drawing on their memories" of Roman law: when faced with a difficult problem, judges may fall back on their Roman learning as a way of thinking through and conceptualizing the issues. But the potential danger with such an approach is one of misremembrance. Alternatively, we may be concerned that such references may be somewhat superficial: of the four speeches which we have considered, two devote real attention to the Roman law position (Lord Rodger in Fairchild and Lord Hope in Foskett), while two mention it in only a single sentence, once in parenthesis. However, to label a reference as superficial is not necessarily negative: Lord Hoffmann in Foskett and Baroness Hale in $O B G$ both referred to Roman law to invoke a particular idea as a way of conceptualizing the relevant issue. Such references are a particular way of using Roman law, of reduction to first principles, rather than a half-hearted attempt at comparative law.

Berg viewed the pursuance of an academic discussion of the Roman law in Foskett as unhelpful because it got in the way of serious issues:

One of Lord Millett's particular concerns was that business ethics in the financial services industry are being undermined by the enormous profit-related incentives which are being given to employees (particularly, the writer would add, senior decision-makers): (1998) L.Q.R. 214 at pp. 216-217. In Foskett $v$. McKeown such considerations were not mentioned. Instead, the Law Lords debated (at pp. 115 and 121-122) whether or not the case would have been categorised as one of confusio by Justinian and earlier Roman jurists. ${ }^{173}$

It has been argued, however, that such criticism fails to appreciate the value of reference to Roman law in assisting judges to define the issues involved in the case. Lewis ${ }^{174}$ has identified that Tindal, C.J., in delivering the judgment of the court in Acton $v$. Blundell, ${ }^{175}$ explained very well indeed why recourse to Roman law could help:

${ }^{173}$ Berg (note 93), 371.

174 A. Lewis, "What Marcellus Says is Against You': Roman Law and Common Law," in A. Lewis and D. Ibbetson, eds., The Roman Law Tradition (Cambridge, 1994), 201-202.

17512 M. \& W. 324, 152 Eng. Rep. 1223 (Ex. Ch. 1843). Lewis cites it as "one of the last [cases] in which original texts of Roman law were cited and discussed as bearing upon the decision to be made in an English court." Lewis (note 174), 200. 
The Roman law forms no rule, binding in itself, upon the subjects of these realms; but in deciding a case upon principle, where no direct authority can be cited from our books, it affords no small evidence of the soundness of the conclusion at which we have arrived, if it proves to be supported by that law, the fruit of the researches of the most learned men, the collective wisdom of ages and the groundwork of the municipal law of most of the countries of Europe. ${ }^{176}$

But there is a second level to the caveat objection which runs deeper: it questions whether the goals of Roman private law align with the goals of modern English law, and whether it is therefore appropriate to resort to Roman jurisprudence. After all, there are marked differences in the proprietary framework of Roman and English law, and the Roman delictual remedies were not available for injury to oneself. It is certainly not, of course, suggested that reference to Roman law is a panacea for all private law problems. The history of the doctrine of mistake in contract illustrates the difficulties inherent in too ready an adoption of alien solutions, as recognized by the Court of Appeal in Great Peace Shipping $v$. Tsavliris Salvage (International) Ltd. ${ }^{177}$

But in the development of the law there are undoubted similarities between the Roman and English approaches, as Markesinis once acknowledged: "the English law of torts and the Roman law of delicts . . . share a common pattern of everwidening but casuistically conceived liability."178 Indeed, it may be argued that the approach of the Roman jurists was more

176 Acton v. Blundell (note 175), 12 M. \& W. at 353.

1772002 E.W.C.A. Civ. 1407, para. 59. See also D. Friedman, "The Objective Principle and Mistake and Involuntariness in Contract and Restitution," Law Q. Rev., 119 (2003), 71-78; and generally C. Macmillan, "Rogues, Swindlers and Cheats: The Development of Mistake of Identity in English Contract Law," Cambridge L.J., 64 (2005), 711.

178 B. S. Markesinis, "The Not so Dissimilar Tort and Delict," Law Q. Rev., 93 (1977), 87. In full:

The English law of torts and the Roman law of delicts thus share a common pattern of ever-widening but casuistically conceived liability. The policy limitations as to what kinds of loss were to be recognised under the Aquilian system, what kinds of plaintiffs were recognised as capable of sustaining loss, what different ways of inflicting loss were to be recompensed, were worked out empirically by juristic interpretation (extending the scope of the civil law action) and the praetors (by means of actiones utiles and in factum). In this method of development the English student will find a familiar phenomenon. 
similar to the English tradition of reasoning than the Scots. ${ }^{179}$ The later recognition and formulation of general principles to rationalize the law in the more modern civilian model should not mislead us in our thinking. Again, we may refer to Lord Rodger's Kelly Lecture:

Roman law and English law worked for so long in this way, one may just perhaps wonder whether the work of formulating statements of principle, as opposed to answering a series of related problems in a mutually consistent manner, is necessarily the highest priority for a living legal system. ${ }^{180}$

If we view the Roman texts as a set of "countless decisions on individual problems," 181 then we can see that they are particularly, perhaps uniquely, relevant to the English incremental development of legal principles. As Lord Rodger has recently remarked both judicially ${ }^{182}$ and extra-judicially, ${ }^{183}$ uncodified systems such as English law and Roman law face a particular challenge from the concurrence of actions, with the consequent dangers of inconsistency:

Complete harmony may well be harder to achieve in an uncodified system - hence the constant attention paid by the classical jurists to the problem - since different remedies will have developed at different times and in response to particular demands. ${ }^{184}$

Another recent illustration of this point can be found in the Court of Appeal decision in Jonathan Yearworth \& Ors v. North Bristol NHS Trust, ${ }^{185}$ where the Court of Appeal drew on Ulpian ${ }^{186}$ in

179 " $[\mathrm{I}] \mathrm{t}$ is undoubtedly the case that the texts of Roman Law which have come down to us do not on the whole contain statements of general legal principles; they contain, rather, countless decisions on individual problems." Rodger (note 83), 15.

180 Id.

181 Id.

182 Gray v. Thames Trains, 2009 U.K.H.L. 33, para. 77.

183 Rodger (note 9), viii.

${ }^{184}$ Gray (note 182), para. 77. Lord Rodger should not, however, be taken to be an enthusiast for codification, as shown by his Maccabaean Lecture, "The Codification of Commercial Law in Victorian Britain," Law Q. Rev., 108 (1992), 570 (= Proc. Brit. Acad., 80 (1991), 149).

1852009 E.W.C.A. Civ. 37. For an analysis of this case, see J. Lee, "The Fertile Imagination of the Common Law: Yearworth v North Bristol NHS Trust," Torts L.J., 17 (2009), 130.

186 Ulpian in D.9.2.13 pr.: Dominus membrorum suorum nemo videtur ("No-one is to be regarded as the owner of his own limbs"), cited in 
determining that it was in principle possible for the male claimants to sue in tort "in respect of damage to bodily substances, namely semen which the men had produced for their possible later use and which the Trust had promised meanwhile to freeze and to store."187 Interestingly, Markesinis and Fedtke suggest that such problems give no cause for reference to Roman law: "[S]ome of the greatest problems now occupying our courts (dealing with, say, matters of . . . in vitro fertilisation . . .) were mischievous ingenuity apart - unknown to the Romans." 188

Finally, with the caveat objection, there perhaps comes a suspicion that reference to Roman law is often a vehicle for the introduction of Scots or European doctrines into English law. If so, an appeal to Roman law would be a wise way of so doing, as it draws on our common legal heritage. But we have seen in the cases under discussion that the judges refer to the Roman law as an independent source of ideas, not as a justification for the importation of alien ideas. These references may be used either to underline the simplicity of the issues, or to explore their complexity. It is hoped that what has been shown here is that judges, when they refer to the work of the jurists, are aided in their attempts to understand the questions involved more clearly.

\section{Post Scriptum}

What, then, does the future hold for Romanists? For his part, Professor Markesinis has noted "the fact that many of our best faculties make [Roman Law] a compulsory [subject]"189 and argues that it "shows how little faith they have in the subject's ability to draw in the crowds." 190 As pointed out by Beatson, this was not accurate at the time of writing, ${ }^{191}$ although Oxford has now reintroduced a compulsory Roman law course for Moderations (first-year examinations) on the B.A. in Jurisprudence. Significantly, however, the course has been somewhat rebranded as "A Roman Introduction to Private Law." This course title better conveys the point of studying Roman law. Whether or not a subject has the ability "to draw in the crowds" does not necessarily speak to its utility or value. The better question is whether we

Yearworth (note 185), by Lord Judge, C.J., giving the judgment of the Court at para. 30.

187 Yearworth (note 185), para. 3.

188 Markesinis with Fedtke (note 11), 14.

189 Markesinis (note 10), 72 n.51.

190 Id.

191 Beatson (note 27), 179. 
have faith in the subject's ability to instruct students (and advocates and academics and judges) in the study of law. It is artificial to separate out an author's Roman learning from his reasoning process in English private law, whether he is a judge or an academic. As Lord Rodger said of Birks, "he could not have produced his book on restitution, which has been such a boon to practitioners groping for an underlying structure, without long years of study of the equivalent field of Roman Law - which happens no longer to be fashionable." 192

To conclude, there is one final sense in which we may use confusio: the term may be used to describe the coming together of Roman and English law: the contemporary use of Roman private law within the English law of obligations. It is tempting to put this point too strongly. Whether the goal of European harmonization of private law ${ }^{193}$ succeeds or not, as Professor Cappelletti observed, it is not to be a question of a "tardy reception of Civil Law by the British Common Law."194 Roman references in three cases, even though they were very important decisions, do not constitute a reception. Instead, as contended by Zimmermann in the Introduction to his opus on the law of obligations, we should recognize that "throughout the centuries, Roman (civil) law never ceased, through various channels, to exercise a considerable influence on English law and jurisprudence."195 It has been argued here that that influence continues today, and that reference to Roman law provides a solid foundation from which to inform the future development of English private law.

192 Rodger (note 83), 9. See too McInnes (note 38), particularly 79-84.

${ }^{193}$ Lewis observes that "[t]he Greek for 'Unification' is 'Homogenisation.' Whilst Unification seems to offer practical advantages, Homogenisation threatens to limit rather than increase understanding." Lewis (note 174), 208.

194 M. Cappelletti, "Introduction," in M. Cappelletti, ed., New Perspectives for a Common Law of Europe (London 1978), 5.

195 Zimmermann (note 143), xi. 